\title{
FOURTH SYMPOSIUM ON APPLIED MATHEMATICS
}

The Fourth Symposium on Applied Mathematics of the American Mathematical Society was held at the University of Maryland, College Park, Maryland, on Friday and Saturday, June 22 and 23, 1951. The subject of the Symposium was Fluid dynamics. Attendance at each of the sessions was approximately 200 . The following 270 persons, including 114 members of the Society, attended:

W. S. Amerst, M. W. Arsove, R. D. Baird, Ronald Bamford, H. C. Beaman, E. G. Begle, A. I. Bellin, F. D. Bennett, R. D. Bennett, D. Bershader, S. Bergman, Robert Betchov, E. E. Betz, Garrett Birkhoff, M. D. Bledsoe, M. J. Block, F. L. Boirtman, R. E. Bower, J. M. Boyer, Charlotte Brudno, R. W. Bryant, J. M. Burgers, R. S. Burington, A. Busemann, John Cangelosi, G. F. Carrier, I. Carstoiu, W. C. Carter, B. B. Cary, A. I. Chalfant, Subrahmanyan Chandrasekhar, C. C. Chang, Y. W. Chen, Peter Chiarulli, B. T. Chu, H. N. Chu, R. V. Churchill, H. G. Cohen, James Conlan, R. D. Cooper, G. M. Corcos, Stanley Corrsin, B. W. Corson, G. R. Costello, F. E. Cothran, C. M. Crenshaw, Tobias Dantzig, K. S. M. Davidson, C. R. DePrima, B. Des Clers De Beaumets, J. B. Diaz, Nicholas Dobi, C. L. Dolph, H. L. Dryden, P. Eisenberg, R. L. Eisenman, W. M. Ellsworth, J. L. Ericksen, Salaman Eskinazi, E. M. Fales, P. H. Fang, F. D. Faulkner, Michael Fekete, Morton Finston, J. W. Fischbach, W. J. Fitzgerald, A. Fiul, Charles Flagle, F. H. Fowler, F. N. Frenkiel, K. O. Friedrichs, A. S. Galbraith, P. R. Garabedian, C. D. Gardner, A. F. Gates, Abolghassen Ghaffari, J. H. Giese, David Gilbarg, L. S. Glover, Michael Goldberg, A. W. Goldstein, R. A. Good, Harold Grad, P. S. Granville, E. C. Gras, Wayland Griffith, R. A. Gross, Karl Guderly, J. M. Gwinn, W. L. Haberman, D. W. Hall, Ryosuke Hama, H. W. Handsfield, P. R. Hardesty, C. M. Hebbert, W. H. Hebrank, A. E. Heins, Aaron Hershfeld, I. R. Hershner, G. J. Higgins, O. H. Hoke, Ralph Hopkins, M. A. Hyman, P. Iribe, S. B. Jackson, S. J. Jacobs, H. T. Jones, M. L. Juncosa, I. Kanter, Carl Kaplan, B. Karlovitz, Theodor von Kármán, S. Karrer, Martin Katzin, C. J. Koch, I. I. Kolodner, Hans Kraft, G. Kuerti, S. H. Lachenbruch, O. E. Lancaster, Frank Lane, Lamar Layton, Patrick Leehey, Eugene Leimanis, Martin Lessen, W. W. Leutert, H. G. Lew, J. A. Lewis, J. V. Lewis, F. W. Light, C. C. Lin, R. K. Lobb, Joseph Logan, M. E. Long, S. C. Lowell, J. G. Loza, J. L. Luckler, G. S. S. Ludford, J. F. Ludloff, J. LuKasiewiez, B. W. McCormick, J. A. McFadden, D. G. McMahon, J. H. McMillen, J. C. MacCormick, H. M. MacNeille, M. S. Macovsky, R. C. Makino, W. R. Mann, P. T. Marshall, M. H. Martin, C. W. Matthews, J. S. Maybee, H. I. Meyer, R. E. Meyer, R. X. Meyer, Joseph Milkman, P. J. Miller, Knox Millsaps, A. J. Mitchell, A. K. Mitchell, G. M. Monroe, E. W. Montroll, F. K. Moore, T. W. Moore, W. E. Moore, M. J. Morkovin, C. R. Morris, F. J. Mulholland, H. Multhopp, C. H. Murphy, W. R. Murray, F. G. Myers, P. W. Nankey, H. E. Newell, O. M. Nikodým, C. O. Oakley, L. Onsager, Simon Ostrach, S. I. Pai, F. D. Parker, C. R. Paulson, J. Pavelka, G. W. Petrie, H. J. Pietrangeli, Y. K. Pieu, Karl Pohlhausen, Harry Polachek, I. Pollyn, H. L. Pond, C. D. Porter, I. R. Pounder, J. O. Powers, William Prager, R. C. Prim, Mozelle Rankin, R. K. Reber, Mina Rees, Eric Reissner, H. S. Ribner, E. K. Ritter, R. C. Roberts, L. V. Robinson, W. G. Rose, Ray Ruetenik, H. C. Sanderson, F. J. Scheid, W. G. Scherberg, T. Schiffman, L. A. Schmidt, R. J. Seeger, O. Seidman, H. D. Seielstad, J. R. Sellars, J. B. Serrin, W. J. Sette, Daniel Shanks, 
R. P. Shaw, A. W. Sherwood, J. T. Sinnette, R. Skalak, Leroy Smith, A. D. Solem, G. L. Spencer, J. R. Spreiter, J. A. Steketee, Joseph Stemberg, Marvin Stern, Joseph Sternberg, M. L. Storm, J. L. Synge, H. S. Tan, Olga Taussky, W. C. Taylor, Feodor Theilheimer, T. Theodorsen, W. R. Thickstun, T. Y. Thomas, R. N. Thurston, John Todd, Stephen Traugott, C. A. Truesdell, Maurice Tucker, J. L. Vanderslice, A. H. Van Tuyl, I. E. Vas, A. E. Von Doenhoff, H. V. Waldinger, J. L. Walsh, Chaio Wang, R. K. Warner, C. N. Warfield, Robert Wasserman, E. C. Watters, Jack Weener, P. P. Wegener, Herschel Weil, H. F. Weinberger, Alexander Weinstein, A. E. Weller, J. R. Weske, W. M. Whyburn, H. L. Wiser, F. H. Wright, Hsuan Yeh, Hideo Yoshihara, D. M. Young, G. B. W. Young, E. H. Zarantonello, P. W. ZettlerSeidel.

The United States Naval Ordnance Laboratory at White Oak, Maryland, served as co-host with the University of Maryland for the Symposium. University dormitories, lounges, and dining facilities were available to those attending the Symposium.

Symposium members and their families were guests at a tea in the Maryland Room of the Home Economics Building on Friday, June 22, 4-6 P.M. A dinner was arranged for those attending the Symposium and their guests on Friday evening. At this dinner greetings were extended by Dr. Ralph D. Bennett, Technical Director of the United States Naval Ordnance Laboratory, and Dean Ronald Bamford of the Graduate School of the University of Maryland. Professor Theodor von Kármán, Honorary President of the International Union on Theoretical and Applied Mechanics, spoke informally at the dinner.

The program of the Symposium consisted of 15 invited addresses, one of which was presented by title. The papers were presented in the following order, the last one, followed by the letter " $t$," being read by title:

1. Subrahmanyan Chandrasekhar: Statistical theory of turbulence.

2. C. C. Lin: A critical discussion of the similarity concepts and their implications in the statistical theory of turbulence.

3. A. Busemann: The non-existence of transonic potential flow.

4. R. E. Meyer: Waves of finite amplitude in ducts of varying crosssection.

5. T. Y. Thomas: Separation of supersonic flow from curved profiles.

6. G. F. Carrier: On the construction of high speed flows.

7. M. H. Martin and W. R. Thickstun: An example of transonic flow for the Tricomi gas.

8. L. Onsager: Statistical hydrodynamics.

9. A. E. Heins: Gravity waves.

10. J. M. Burgers: Non-uniform propagation of shock waves. 
11. T. Theodorsen: Theory of propellers.

12. Garrett Birkhoff: Numerical methods in conformal mapping.

13. J. L. Synge: Flow of viscous liquid through pipes and channels.

14. Alexander Weinstein: The method of singularities in the physical and in the hodograph plane.

15t. S. R. De Groot: Fluid dynamics and hydrodynamics.

The presiding officers at the sessions were, respectively: Dr. H. L. Dryden, Director, National Advisory Committee for Aeronautics; Professor K. O. Friedrichs, New York University; Dr. Harry Polachek, United States Naval Ordnance Laboratory; and Professor William Prager, Brown University.

At the beginning of the Saturday afternoon session a resolution of thanks and appreciation for the hospitality extended was presented by Professor C. O. Oakley and unanimously adopted.

The papers presented at the Symposium will be published as volume four of the Proceedings of the Symposia in Applied Mathematics by the McGraw-Hill Book Company.

M. H. Martin,

Chairman of the

Committee on Arrangements
W. M. WhyBuRn, Associate Secretary of the Society 